\title{
Revisiting the Energy Consumption-Growth Nexus for Croatia: New Evidence from a Multivariate Framework Analysis
}

\author{
Nela Vlahinic ${ }^{1}$, Pavle Jakovac ${ }^{1}$
}

\begin{abstract}
This paper applies the most recently developed autoregressive distributed lag (ARDL) co-integration procedure to re-investigate co-integration and the causal relationship between energy consumption and real GDP within a multivariate framework that includes capital stock and labor input for Croatia during the 1952-2011 period. The empirical results fully support a positive longrun co-integrated relationship between production inputs and real GDP and the important role of energy in economic growth. It is found that a unidirectional causality runs from total final energy consumption to real GDP in the long run and that a bidirectional causality in the short run, which means that energy is a necessary requirement for economic growth. Additionally, the reduction in energy consumption could adversely affect GDP in the short and long run. Therefore, Croatia should adopt a more vigorous economic policy aimed toward increasing investments in installed energy capacities and reforming the economic structure towards re-industrialization and more energy-efficient industries.
\end{abstract}

KEY WORDS: $\quad$ economic growth; energy consumption; ARDL; Croatia

JEL Classification: Q43

${ }^{1}$ University of Rijeka - Faculty of Economics, Croatia

\section{Introduction}

During the last two decades, a number of papers have addressed the causality between economic growth and energy consumption. Although a strong interdependence and causality between economic growth and energy consumption represent a stylized economic fact, the existence and direction of the causality is still not clearly defined. Most studies have been based on a bivariate approach that explores the causal relationship between energy consumption and output (GDP). This

-

Correspondence concerning this article should be addressed to: Pavle Jakovac University of Rijeka - Faculty of Economics Ivana Filipovica 4 Rijeka 51000 Croatia. E-mail: pjakovac@efri.hr approach has limitations and is not able to capture the multivariate framework within which the changes in energy use are frequently countered by the substitution of other factors of production, resulting in an insignificant overall impact on output. In the theoretical framework of the energy-dependent Cobb-Douglas function that involves energy as the third input, this paper tests co-integration of three inputs (capital, labor and energy) and GDP in Croatia. The time period used in this analysis is 1952-2011, which covers a long-term period during which substitution among production inputs could occur. The main aim of the paper is to empirically determine whether a causal link exists among capital stock (as a proxy for capital), employment (as a proxy for labor), total final energy consumption (as 
a proxy for energy) and economic growth in Croatia.

Although a few papers have focused on the relationship between energy consumption and GDP in Croatia, to the best of our knowledge, no paper yet has tested this causality within a multivariate framework. A year ago (July $1^{\text {st }}, 2013$ ), Croatia became the new $28^{\text {th }}$ EU member state, and its energy policy is strongly influenced by the EU Energy Policy. The EU's national energy policy aims to achieve three underlying goals by 2020 known as the " $20-20-20$ " targets, i.e., improving energy efficiency by a $20 \%$ reduction in primary energy use, reducing EU greenhouse gas emissions to at least $20 \%$ below 1990 levels, and shifting 20\% of EU energy consumption to renewable energy sources. Therefore, the issue of the relationship between energy consumption and economic growth has become a crucial energy and economic policy topic, especially in a small and energy-dependent economy vulnerable to exogenous energy shocks.

The paper is organized in the following manner. Section 2 provides the theoretical framework for the multivariate co-integration analysis, Section 3 presents a literature review on empirical testing, and Section 4 describes the data and econometric methodology and summarizes the obtained empirical results. The final section closes with conclusions.

\section{Theoretical framework for multivariate co-integration analysis}

Standard neo-classical economic theory explains output (GDP) as a function of two independent variables, i.e., capital (K) and labor (L), where the cost share of each production factor is equal to its output elasticity (or marginal productivity). Neo-classical economic theory explains the economy as a closed system in which output is produced by the inputs of labor and capital. Therefore, economic growth is the result of increased inputs or their quality. Energy inputs have indirect importance and have been viewed as intermediate inputs. According to Stern (1999), mainstream economists have accepted the concept of primary and intermediate factors of production. Primary factors of production are inputs that exist at the beginning of the period under consideration and are not directly consumed in production (although they can be degraded and can be added to), whereas intermediate inputs are those created during the production period under consideration and are consumed entirely during production. Capital, labor and land are the primary factors of production, and such goods as fuels and materials are intermediate inputs. This approach has led to a focus in mainstream growth theory on primary inputs, especially capital and labor, whereas intermediate inputs such as energy have an indirect role. Generally, the neo-classical production function explains economic growth with an increase in labor, capital and technology in which total factor productivity (TFP) is the portion of output that cannot be explained by the amount of inputs used in the production. The TFP growth is usually measured by the Solow residual, although it accurately measures TFP growth only if the production function is neoclassical, i.e., if there is perfect competition in factor markets and if the growth rates of the inputs are measured accurately (Stern, 1999).

After the first oil crisis in 1973-74, certain economists began to formulate energy-dependent production functions that included energy and materials in addition to conventional labor and capital inputs (e.g., Berndt \& Wood, 1979; Hannon \& Joyce, 1981; Tintner et al., 1977). This approach retained the condition of constant returns to scale and the equality assumption, i.e., that factor elasticities should be equal to the factor payments share in the national accounts. According to Ayres and Warr (2009), this three-factor model is implicitly a two-sector model because the cost of energy (E) in practice is not defined in terms of payments to "nature" but rather to extractive industries that own energy resources. However, the introduction of the third input (E) causes certain theoretical and methodological problems. First, the interpretation of the factor payments shares is no longer valid in the three-factor case. Although payments to labor (wages, salaries) and payments to capital (dividends, interests, royalties) are clear, payments to energy per se do not exist and are in fact payments to energy resource owners, mostly for capital and labor. Energy is not a tangible commodity, and only added value can be captured by the investment of labor and physical capital. Still, capital and labor do not actually create the energy itself.

Second, the theoretical assumption of the CobbDouglas production function is that all combinations of the three independent variables (K, L and $\mathrm{E}$ ) are possible and account for the output of an economy. 

labor (but not energy) must sum to unity, Stern did not find co-integration. Oh and Lee (2004) investigated the causal relationship between energy consumption and economic growth in Korea by applying a multivariate model of capital, labor, energy and GDP. Empirical results for Korea over the period 1970-1999 suggested a long-run bidirectional causal relationship between energy and GDP and short-run unidirectional causality running from energy to GDP. The source of causation in the long run was found to be the error correction terms in both directions. Stresing, Lindenberger, \& Kümmel (2008) applied co-integration analysis to output, capital, labor and energy for Germany, Japan and the USA since 1960 and confirmed the existence of co-integration. These researchers also found that the output elasticities for energy are much larger than the cost shares of this factor. However, output elasticities for labor are much smaller than the cost share of the labor. In the previously mentioned study, Ayres and Warr (2009) also found that capital, labor, energy (exergy) and output are co-integrated. The calculated output elasticity of energy is up to ten times higher than its cost share, whereas "pure" (unskilled) labor in the absence of machines and sources of power is nearly unproductive at the margin.

With respect to studies on Croatia, the new $28^{\text {th }} \mathrm{EU}$ member state, no papers have addressed the multivariate framework, although several papers analyzed bivariate co-integration between energy consumption and GDP (Borozan, 2013; Gelo, 2009; Vlahinic-Dizdarevic and Zikovic, 2010). These findings differ due to different methodologies and time frames. Gelo (2009) used the VAR and Granger causality test to analyze the causal relationship between annual GDP and total energy consumption from 1953 to 2005 in Croatia and concluded that GDP Granger causes total energy consumption and that total energy consumption and the constant are not significant in the VAR model, whereas GDP is significant. Similar results were obtained in the work of Vlahinic-Dizdarevic and Zikovic (2010), which examined the causal relationship between several energy variables (energy consumption in industry and households, oil consumption, primary energy production and net energy imports) and real GDP in the period 1993-2006. These researchers found co-integration for all of the tested relationships and causality that again runs from real GDP growth to all energy variables. The same authors (Zikovic \& Vlahinic-Dizdarevic, 2011) examined the causal relationship between oil consumption and economic growth for 22 small European countries, including Croatia, over the period 1980-2007 and employed the error correction model (ECM). Their results show that small European states could be divided into two groups with respect to the direction of causality. Croatia belongs to the group of countries (mostly developed ones) in which the causality runs from real GDP to oil consumption. In contrast, Borozan (2013) found that total energy consumption Granger causes real GDP using bivariate vector autoregression (VAR) and Granger causality tests covering the period from 1992 to 2010 . Confronting the results of these studies require further analysis within longer time periods and more complex and superior methodology frameworks based on multivariate co-integration analysis.

\section{Data and methodology}

\section{Data}

All of the data used in this paper consist of annual time series for the period 1952-2011 to cover a longterm period during which substitution among production factors occurred. The variables for the energy consumption/economic growth hypothesis are real gross domestic product (GDP), capital stock (K), employment (L), and total final energy consumption (TFEC). The real GDP data (in millions of US\$ at 2000 constant prices) were originally obtained from Druzic and Tica (2002). Figures covering real GDP were subsequently expanded with data on real GDP growth rates from the Croatian Bureau of StatisticsCBS (2012). The capital stock variable (K) was generated using the GDP data and the data on gross fixed capital formation in fixed assets from the Croatian Statistical Yearbooks and World Bank (2012) because there are no readily available data for Croatia's capital stock. For the initial capital stock, we divided real fixed investment in the first period (1952, the first year of our analysis) with the sum of depreciation rate (5\%) and the average growth rate of investment (Hall \& Jones, 1999; Kyriacou 1991). The capital stock data for the remainder of the observed period were generated using the linear perpetual inventory method (PIM) and the following equation: 

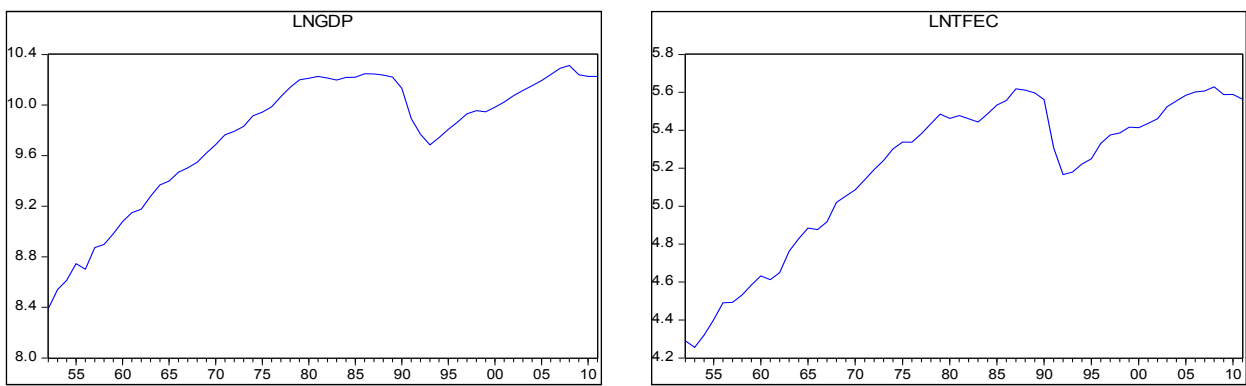

Figure 1. Plots of variables (Druzic and Tica, 2002; CBS, 2012; ElHP, 2012)

$K_{t}=\sum_{i=0}^{n-1}\left(1-\frac{i \delta}{2}\right) I_{t-i}+(1-n \delta) K_{t-n}$

where $K$ represents physical capital, $I$ denotes investments and $\delta$ is the rate of depreciation. To increase the realism of the estimates, equation (1) differs from the standard linear PIM equation for depreciation of new investment (namely, $\delta$ is divided by 2 ) because new investments are assumed to be placed in service at midyear instead of at the end of the year. According to Kamps (2004), investment typically occurs throughout the year and not only at the end of the year. Employment (L) data, due to methodological issues in the preand post-transition periods, presents the number of employed people (in thousands) excluding those employed in public administration, police and defense. These figures were retrieved from Croatian Bureau of Statistics [CBS] (2012) and Raguz, Druzic and Tica (2011). Total final energy consumption data (TFEC, in petajoules) were obtained from the Energy Institute Hrvoje Pozar [EIHP] (2012) and exclude conversion losses, energy sector own use, transmission losses and non-energy use.

For estimation purposes, all variables are transformed into natural logarithms to reduce heteroscedasticity and to obtain the growth rate of the relevant variables according to their differenced logarithms (Chang, Fang, \& Wen, 2001; Fatai, Oxley, \& Scrimgeour, 2004; Ozturk \& Acaravci, 2010). To graphically visualize the variables, Figure 1 depicts only Croatia’s total final energy consumption and gross domestic product.
Figure 1 indicates that a structural break might be present in these series. Using the Chow breakpoint test (Chow, 1960), we recognize that lnGDP (F-statistic $=5.258663)$ and lnTFEC $($ F-statistic $=1.767822)$ are "broken" in the year 1990 at the $1 \%$ and exactly the $10 \%$ significance level, respectively.

Several reasons can be attributed to this break in data. In 1990, the Croatian economy was faced with a negative growth rate, hyperinflation and the collapse of the so-called self-managing (market) socialism (or workers' self-management) as the dominant economic system in ex-Yugoslavia. The GDP decreased as a result of the transition depression and the Croatian Homeland War, which began in 1991 after Croatia terminated all state and legal relations with the former Socialist Federal Republic of Yugoslavia. Selected estimates (Pasalic, 1999, pp. 38) indicate that in the period from 1990 to 1993 , the indirect damage to the Croatian economy due to the war was equivalent to a loss of $109 \%$ of the annual average GDP. Industrial production dropped sharply as the result of the closure and restructuring of heavy industry, which was the largest energy consumer, and thus, the energy consumption in industry decreased considerably. The uncompetitive position of Croatian industry has been additionally enforced by a strong national currency and extensive trade liberalization, which led to further declines in industrial production and industrial energy consumption. Since then, the Croatian economy has been oriented primarily towards services, especially tourism, and light industries (e.g., 
food processing, pharmaceuticals, textile industry) that are not energy intensive (Vlahinic-Dizdarevic \& Zikovic, 2010). As a result of the transition depression and structural changes, the total final energy consumption declined sharply after 1990. To account for the mentioned structural break, variable D1990 is introduced in the analysis (a dummy variable equal to 1 for the period 1990-1993 and 0 otherwise). We have additionally introduced a second dummy variable D2009 (equal to 1 for the period 2009-2011 and 0 otherwise) to reflect the ongoing economic downturn in Croatia and to make the results more robust.

\section{Methodology}

\section{Unit root tests}

Because many macroeconomic series are non-stationary (Nelson \& Plosser, 1982), unit root tests are important and useful in examining whether the variables in question are stationary (or not). In other words, unit root tests are required to investigate the order of integration of the variables. This factor is also important in obtaining an unbiased estimation from the Granger causality tests.

Because there is no uniformly powerful test of the unit root hypothesis (Gujarati \& Porter, 2009) and to determine the order of the series in more robust manner, we conducted five different unit root tests, as suggested by Soytas and Sari (2007) and Sari, Ewing and Soytas (2008). We used the Augmented Dickey-Fuller (ADF) test (Dickey \& Fuller, 1979), Phillips-Perron (PP) test (Phillips \& Perron, 1988), KwiatkowskiPhillips-Schmidt-Shin (KPSS) test (Kwiatkowski et al., 1992), Elliot-Rothenberg-Stock Dickey-Fuller GLS de-trended (DF-GLS) test (Elliot et al., 1996) and NgPerron $\mathrm{MZ}_{\mathrm{t}}\left(\mathrm{NG}-\mathrm{P}\left(\mathrm{MZ}_{\mathrm{t}}\right)\right.$ ) test (Ng \& Perron, 2001). The reason for the use of five different tests is to establish the order of integration without any arbitrary decisions while bearing in mind the size (the level of significance) and power (the probability of rejecting the null hypothesis $\mathrm{H}_{0}$ when it is false) of these tests. We do not discuss the details of the unit root tests in this work (see Maddala \& Kim (1998) for a review of ADF, PP, KPSS, and DF-GLS and Ng-Perron (2001) for additional information on NG-P).

Although the ADF and PP tests are criticized due to their low power properties (Soytas and Sari, 2007), which make their results potentially less reliable, they are included in this analysis. The same problem can be attributed to the DF-GLS test, especially if the number of observations is less than 50 (which is not the case in this study), according to Elliot et al. (1996). However, the poor size and power properties problem is solved by the NG-P unit root test. According to Maddala and Kim (1998), KPSS is used to verify the results of the $\mathrm{ADF}$ and PP tests (although it also suffers from the same low power problems).

\section{ARDL bounds testing approach to co-integration}

Two variables are said to be co-integrated if they share a common trend. According to Engle and Granger (1987), a linear combination of two (or more) nonstationary series may be stationary. If such a stationary linear combination exists, the series are considered co-integrated. Due to the existence of co-integration (namely, the long-run equilibrium relationship), although the variables are individually non-stationary, they can deviate from the equilibrium in the short run but must return to it in the long run. Generally speaking, the variables cannot drift further away from each other arbitrarily (Binh, 2011), and the differences between them do not change drastically over time.

The most widely used methods for empirical analysis of the long-run relationship and dynamic interactions between two or more variables include Engle and Granger's (1987) two-step procedure and the multivariate maximum-likelihood-based approach of Johansen (1988) and Johansen and Juselius (1990). However, these approaches require that the variables in question must be integrated in order one, which inevitably involves a step of stationarity pre-testing, thus introducing a certain degree of uncertainty into the analysis (Esso, 2009). In addition, Engle-Granger is only appropriate for two variables, although there may be a possible co-integration relationship among several variables. In contrast, Johansen's multivariate approach has a problem with the degrees of freedom if applied to a small sample (Toda, 1994).

To avoid the restrictions mentioned above, this study applied the recently developed autoregressive distributed lag (ARDL) co-integration procedure introduced by Pesaran, Shin and Smith (2001). According to Pesaran et al. (2001), the ARDL co-integration approach has several advantages over other techniques 
of co-integration. First, this technique can be applied regardless of whether the underlying regressors are $\mathrm{I}(0), \mathrm{I}(1)$ or a combination of both with no need for unit root pre-testing. Although pre-testing of a unit root can be exempted if applying a bounds testing approach to co-integration, according to Shahbaz, Tang, \& Shahbaz Shabbir (2011), it is essential to determine the order of integration for each variable to avoid inclusion of $\mathrm{I}(2)$ variables. It is not necessary that all variables are $\mathrm{I}(0)$ and/or I(1). If any of the variables are indeed I(2), then the ARDL procedure will give spurious results. Second, the model takes a sufficient number of lags to capture the data generating process in general for specific modeling frameworks and allows the variables to have different optimal lags. Third, the error correction model can be derived from ARDL through a simple linear transformation, which integrates shortrun adjustments with the long-run equilibrium without loss of long-run information. Fourth, the small sample properties are superior to those of the Johansen co-integration technique. Fifth, endogeneity is less of a problem in the ARDL technique because it is free of residual correlation. Finally, the ARDL procedure employs a single reduced form equation, whereas the conventional co-integration procedures estimate the long-run relationship within a context of system equations (Acaravci, 2010; Dantama, Abdullahi, \& Inuwa, 2012; Ozturk \& Acaravci, 2010).

The bounds-testing procedure consists of estimating an unrestricted error correction model with the following generic form (equation 2) in which each variable is used as a dependent variable:

$$
\begin{aligned}
& \Delta \ln G D P_{t}=\alpha_{10}+\alpha_{1} D 1990_{t}+\alpha_{\mathrm{B}} D 2009_{t}+\sum^{n} \alpha_{13} \Delta \ln G D P_{t-i}+ \\
& +\sum^{n} \alpha_{14} \Delta \ln K_{t-i}+\sum^{n} \alpha_{15} \Delta \ln L_{t-i}+\sum^{n} \alpha_{16} \Delta \ln T F E C_{t-i}+
\end{aligned}
$$$$
+\delta_{1} \ln G D P_{t-1}+\delta_{12} \ln K_{t-1}+\delta_{13} \ln L_{t-1}+\delta_{14} \ln T F E C_{t-1}+\varepsilon_{1 t}
$$

An F-test for the joint significance of the lagged level variables coefficients is conducted to examine whether a co-integrating relationship exists among the variables. The null hypothesis of no co-integration $\left(\mathrm{H}_{0}\right)$ against the alternative $\left(\mathrm{H}_{1}\right)$ for each equation is stated as follows: $\mathrm{H}_{0}: \delta_{11}=\delta_{12}=\delta_{13}=\delta_{14}=0$ and $\mathrm{H}_{1}: \delta_{11} \neq \delta_{12} \neq$ $\delta_{13} \neq \delta_{14} \neq 0$. The F-test has a non-standard distribution, and two sets of critical values are provided by Pesaran et al. (2001). One set refers to the I(1) series and the other to the $\mathrm{I}(0)$ series, which are known as the upper bound (UCB) and lower bound critical values (LBC), respectively. Given that Pesaran et al.s (2001) critical values are computed for a large sample (namely, 5001000 observations), Narayan (2005) estimated a new set of critical values for small samples ranging from 30 to 80 observations. Because our sample size is 60 observations, we use the critical values provided by Narayan (2005).

A decision on whether co-integration indeed exists between the dependent variable and its regressors is made as follows (Bartleet \& Gounder, 2010; Chandran, Sharma, \& Madhavan, 2010; Kouakou, 2011). If the computed F-statistic is greater than the upper bound of the critical value, the null hypothesis of no co-integration $\left(\mathrm{H}_{0}\right)$ is rejected. If the computed F-statistic is less than the lower level band, we fail to reject $\mathrm{H}_{0}$, which signifies the absence of co-integration. If the computed F-statistic falls inside the upper and lower bounds, a conclusive inference cannot be made.

\section{Granger causality}

In everyday life, if an event A causes event B, in such a situation, the event $B$ is no more than a result (or consequence) of the event A (Bahovec \& Erjavec, 2009). The concept of "causality" in an econometric sense, following Granger (1969), assumes a different meaning. The so-called Granger causality implies causality in the prediction (forecast) sense rather than in a structural sense (Chontanawat, Hung, \& Pierse, 2008). In other words, the term "causality" does not imply that a variable Y (or X) is the effect or the result of variable $\mathrm{X}$ (or Y) but represents a possibility of investigating how much of the current $\mathrm{Y}$ ( or X) can be explained by the past values of $\mathrm{Y}$ (or $\mathrm{X}$ ) and whether adding lagged values of X (or Y) can improve the explanation (Gujarati \& Porter, 2009).

The ARDL (or any other) co-integration method tests the existence or absence of long-run relationship between the variables; it does not indicate the direction of causality (Ozturk \& Acaravci, 2011).

Thus, if we find no evidence of a long-run relationship among the variables, the traditional Granger causality test, i.e., a vector autoregressive (VAR) model specified in first difference form, will be conducted as a valid causality testing solution. A VAR model might 
suggest a short-run relationship between the variables because the long-run information is removed in the first differencing. An error correction model (ECM) can avoid such shortcomings (Vlahinic-Dizdarevic \& Zikovic, 2010). In other words, the ECM is a means of reconciling the variable's short-run behavior with its behavior in the long run (Gujarati \& Porter, 2009). However, if there is evidence of co-integration between the variables, the Granger causality test should include a one-period lagged error correction term $\left(\mathrm{ECT}_{\mathrm{t}-\mathrm{1}}\right)$ as an additional independent variable in the equation (Ouédraogo, 2010). Hondroyiannis, Lolos and Papapetrou (2002) argue that the error correction term measures the proportion by which the long-term imbalance in the dependent variable is corrected in each short-run period. The size (together with the negative sign) and the statistical significance of the ECT measure the extent to which each dependent variable has the tendency to return to its long-run equilibrium. Accordingly, we must estimate the following long-run and short-run models presented in equations (3) and (4):

$$
\begin{aligned}
& \ln G D P_{t}=\alpha_{20}+\alpha_{21} D 1990_{t}+\alpha_{22} D 2009_{t}+ \\
& +\sum_{i=1}^{n} \alpha_{23} \ln G D P_{t-i}+\sum_{i=1}^{n} \alpha_{24} \ln K_{t-i}+\sum_{i=1}^{n} \alpha_{25} \ln L_{t-i}+ \\
& +\sum_{t-1}^{n} \alpha_{26} \ln \text { TFEC }_{t-1}+\varepsilon_{2 t}
\end{aligned}
$$

$$
\begin{aligned}
& \Delta \ln G D P_{t}=\alpha_{30}+\alpha_{31} D 90+\alpha_{32} D 2009_{t}+ \\
& +\sum_{i-1}^{n} \alpha_{33} \Delta \ln G D P_{t-i}+\sum_{i-1}^{n} \alpha_{34} \Delta \ln K_{t-i}+ \\
& +\sum_{i-1}^{n} \alpha_{35} \Delta \ln L_{t-i}+\sum_{i-1}^{n} \alpha_{36} \Delta \ln \text { TFEC }_{t-i}+ \\
& +\varphi_{1} E C T_{t-1}+\varepsilon_{3 t}
\end{aligned}
$$

where $\varphi$ is the coefficient of the error correction term, which shows how quickly the variables converge to equilibrium and must have a statistically significant coefficient with a negative sign.

\section{Empirical results and discussion}

\section{Unit root test results}

Both "intercept and trend" and "intercept" regressors were included in the test equation in all five previously mentioned unit root tests. For the purposes of the ADF, DF-GLS and NG-P unit root tests, the Schwarz information criterion (SIC) is used to determine the number of lags, whereas the Newey-West method is applied to choose the optimal lag length (or bandwidth) for the purposes of the PP and KPSS unit root tests. The critical values for the ADF and PP tests are taken from MacKinnon (1996). For KPSS, the critical values are taken from Kwiatkowski et al. (1992). The critical values for DF-GLS are taken from Elliott, Rothenberg and Stock (1996), and the NG-P (MZ) critical values are taken from $\mathrm{Ng}$ and Perron (2001). All unit root tests have a null hypothesis $\left(\mathrm{H}_{0}\right)$ stating that the series in question has a unit root against the alternative that it does not. The null hypothesis $\left(\mathrm{H}_{0}\right)$ of KPSS, however, states that the variable is stationary. The results for all five unit root tests summarized in Table 1 reveal that all variables are non-stationary at level but become stationary after first difference.

The variable $\operatorname{lnK}$ was smoothed using the HoltWinters multiplicative model (Winters, 1960) because it remained non-stationary after the first difference according to all unit root tests using both "intercept and trend" and "intercept" as exogenous regressors. Exponential smoothing showed that the (new) variable lnKSM was stationary after the first difference. The only exception is the NG-P unit root test, solely under the "intercept and trend" assumption. In general, the combined results of all unit root tests suggest that all variables appear to be $\mathrm{I}(1)$ processes, and hence, they have an integration order of 1 .

\section{Co-integration and causality results}

After determining the order of integration of each variable, the next step evaluates whether the variables used in the analysis are co-integrated. Although the correlation between our variables is high (0.990744), this does not directly imply that they are co-integrated. An important issue in applying a bounds testing approach to co-integration is the selection of the optimal lag length. In a situation in which the chosen lag length is less than the actual lag length, the omission of relevant lags can cause bias. However, in a situation in which the chosen lag length is greater than the actual one, the inclusion of irrelevant lags in the equation provides inefficient estimates and does not give the expected results (Bahovec \& Erjavec, 2009). We set the 
Table 1. Unit root test results

\begin{tabular}{|c|c|c|c|c|c|c|}
\hline & Variables & ADF & PP & KPSS & DF-GLS & NG-P (MZt) \\
\hline \multicolumn{7}{|c|}{ Panel A: Log levels } \\
\hline \multirow{5}{*}{ 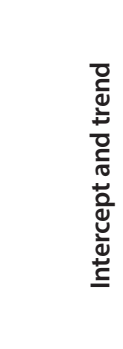 } & $\operatorname{lnGDP}$ & $-1.774678(1)$ & $-2.081557(4)$ & $0.212407^{\mathrm{b}}(6)$ & $-0.964223(1)$ & $-1.01515(1)$ \\
\hline & $\ln K$ & $-2.736872(1)$ & $-1.313444(5)$ & $0.226876(6)$ & $-2.282304(1)$ & $-2.78198^{b}(1)$ \\
\hline & $\operatorname{lnL}$ & $-2.209397(1)$ & $-1.980041(4)$ & $0.221302(6)$ & $-1.219260(1)$ & $-1.35900(1)$ \\
\hline & InTFEC & $-2.194499(1)$ & $-1.473599(2)$ & $0.213523^{b}(6)$ & $-1.604199(1)$ & $-1.46536(1)$ \\
\hline & $\operatorname{lnKSM} M^{*}$ & $-2.036284(1)$ & $-1.291062(5)$ & $0.224998(6)$ & $-1.426610(1)$ & $-1.31293(1)$ \\
\hline \multicolumn{7}{|c|}{ Panel B: Log first differences } \\
\hline \multirow{5}{*}{ 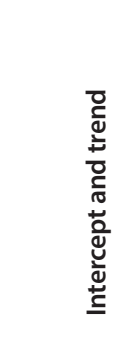 } & $\operatorname{lnGDP}$ & $-4.846048(0)$ & $-4.908813(2)$ & $0.115346(4)$ & $-4.521034(0)$ & $-3.33133^{b}(0)$ \\
\hline & $\operatorname{lnK}$ & $-2.202118(1)$ & $-2.132854(2)$ & $0.119512 c(5)$ & $-2.148090(1)$ & $-2.17078(1)$ \\
\hline & $\ln \mathrm{L}$ & $-3.864181^{b}(0)$ & $-3.872742^{b}(1)$ & $0.082883(4)$ & $-3.930527(0)$ & $-3.11918(0)$ \\
\hline & InTFEC & $-4.840828(0)$ & $-4.942047(1)$ & $0.073038(2)$ & $-4.284857(0)$ & $-3.22673^{b}(0)$ \\
\hline & $\operatorname{lnKSM}{ }^{*}$ & $-3.494746^{b}(0)$ & $-3.532204^{b}(2)$ & $0.117649(5)$ & $-2.920148 c(0)$ & $-2.49715(0)$ \\
\hline
\end{tabular}

\section{Panel C: Log levels}

\begin{tabular}{|c|c|c|c|c|c|c|}
\hline & InGDP & $-2.492388(1)$ & $-3.293755^{a}(4)$ & $0.714990^{b}(6)$ & $0.058811(1)$ & $0.13266(1)$ \\
\hline & InK & $-1.985301(2)$ & $-2.509414(5)$ & $0.863484(6)$ & $-0.334392(2)$ & $-0.59436(2)$ \\
\hline 응 & $\ln \mathrm{L}$ & $-3.025856^{a}(1)$ & $-3.528875^{a}(4)$ & $0.689648^{b}(6)$ & $-0.527996(1)$ & $-0.42113(1)$ \\
\hline 总 & InTFEC & $-2.766034^{b}(1)$ & $-2.346234(2)$ & $0.772562(6)$ & $-0.457216(1)$ & $-0.12035(1)$ \\
\hline
\end{tabular}

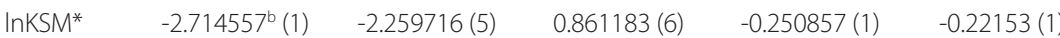

\section{Panel D: Log first differences}

\begin{tabular}{|c|c|c|c|c|c|c|}
\hline \multirow{4}{*}{ 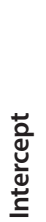 } & InGDP & $-4.476723(0)$ & $-4.480993(2)$ & $0.520704^{a}(4)$ & $-2.932493(0)$ & $-2.51135^{b}(0)$ \\
\hline & InK & $-1.809140(1)$ & $-1.654028(2)$ & $0.418114^{c}(6)$ & $-1.834444^{b}(1)$ & $-1.85090^{b}(1)$ \\
\hline & $\operatorname{lnL}$ & $-3.247360^{b}(0)$ & $-3.247360^{b}(0)$ & $0.527035^{a}(5)$ & $-3.002914(0)$ & $-2.58565(0)$ \\
\hline & InTFEC & $-4.425697(0)$ & $-4.425697(0)$ & $0.355486^{b}(3)$ & $-3.710502(0)$ & $-3.00167(0)$ \\
\hline & $\operatorname{lnKSM}{ }^{*}$ & $-2.866760^{c}(0)$ & $-2.838317^{c}(2)$ & $0.414624^{b}(5)$ & $-2.510837^{b}(0)$ & $-2.26446^{b}(0)$ \\
\hline
\end{tabular}

Note: Optimal lag lengths are shown in parenthesis. The maximum lag length considered is 10 . a, b, c indicate the $1 \%, 5 \%$ and 10\% significance levels, respectively. Source: Authors' calculation using EViews 7.1 
Table 2. ARDL co-integration test results

\begin{tabular}{|c|c|c|}
\hline & Model 1 & Model 2 \\
\hline Dependent variable & $\operatorname{lnGDP}$ & InTFEC \\
\hline Function & FInGDP(InGDP|InKSM, InL, InTFEC) & FInTFEC (InTFEC $\mid \operatorname{lnGDP}, \operatorname{InKSM}, \operatorname{InL})$, \\
\hline F-statistic & $4.1012^{c}$ & $3.3918^{b}$ \\
\hline Decision & Co-integration & No co-integration \\
\hline
\end{tabular}

Note: $a, b, c$ Indicate the 1\%, 5\% and 10\% significance levels, respectively. Critical values of the F-statistic for 60 observations are taken from Narayan (2005, pp. 1988), case III: intercept and no trend with k=2 regressors. Source: Authors' calculation using MICROFIT 4.1

Table 3. Results of Johansen's co-integration test

\begin{tabular}{lcccc}
\hline Ho & Eigenvalue & Trace statistics & $\mathbf{0 . 0 5}$ critical value & Prob. \\
\hline None* $^{*}$ & 0.321954 & 48.33264 & 47.85613 & 0.0451 \\
At most 1 & 0.256471 & 26.18583 & 29.79707 & 0.1233 \\
At most 2 & 0.143555 & 9.294054 & 15.49471 & 0.3389 \\
At most 3 & 0.008056 & 0.461050 & 3.841466 & 0.4971
\end{tabular}

Trace test indicates 1 co-integration equation at the $5 \%$ level.

Co-integrating vector: InGDPt $=1.3454 \mathrm{InTFEC}_{t}$

$$
\text { (3.2433) }
$$

Note: * Denotes rejection of the hypothesis at the $5 \%$ level. Critical values are taken from MacKinnon, Haug and Michelis (1999). Figures in parenthesis are t-statistics. Co-integrating vector only shows significant variable(s). Source: Authors' calculation using EViews 7.1

maximum lag length at three years, which is sufficiently long for the annual data to capture the dynamic relationship (Tang \& Shahbaz, 2011), and the AIC statistic is used to choose the best ARDL model (Lütkepohl, 2005). The results of the ARDL co-integration test are reported in Table 2.

The null hypothesis of no co-integration $\left(\mathrm{H}_{0}\right)$ can be rejected if $\operatorname{lnGDP}$ is treated as the dependent variable because the calculated F-statistic (4.1012) is higher than the upper bound critical value (3.923) suggested by Narayan (2005) at the $10 \%$ level of significance. This situation indicates that there exists a long-run relationship between GDP and energy consumption (and other forcing variables). However, if we take the total final energy consumption into consideration as the dependent variable, the calculated F-statistic (3.3918) is lower than the lower bound critical value (3.415) at the $5 \%$ significance level. In the case of lnTFEC serving as the dependent variable, there is no evidence of any co-integration.

For robustness of the results, Table 3 includes the trace statistics results of the Johansen multivariate co-integration approach. According to Dergiades and Tsoulfidis (2011), the ARDL and Johansen's techniques for co-integration, despite their differences, should not be viewed as mutually exclusive but as complementary to each other.

As shown from Table 3, the ARDL co-integration test results are verified by the Johansen's test, indicating at least one co-integration vector. The optimal lag 
Table 4. Long-run and short-run estimates - Model 1

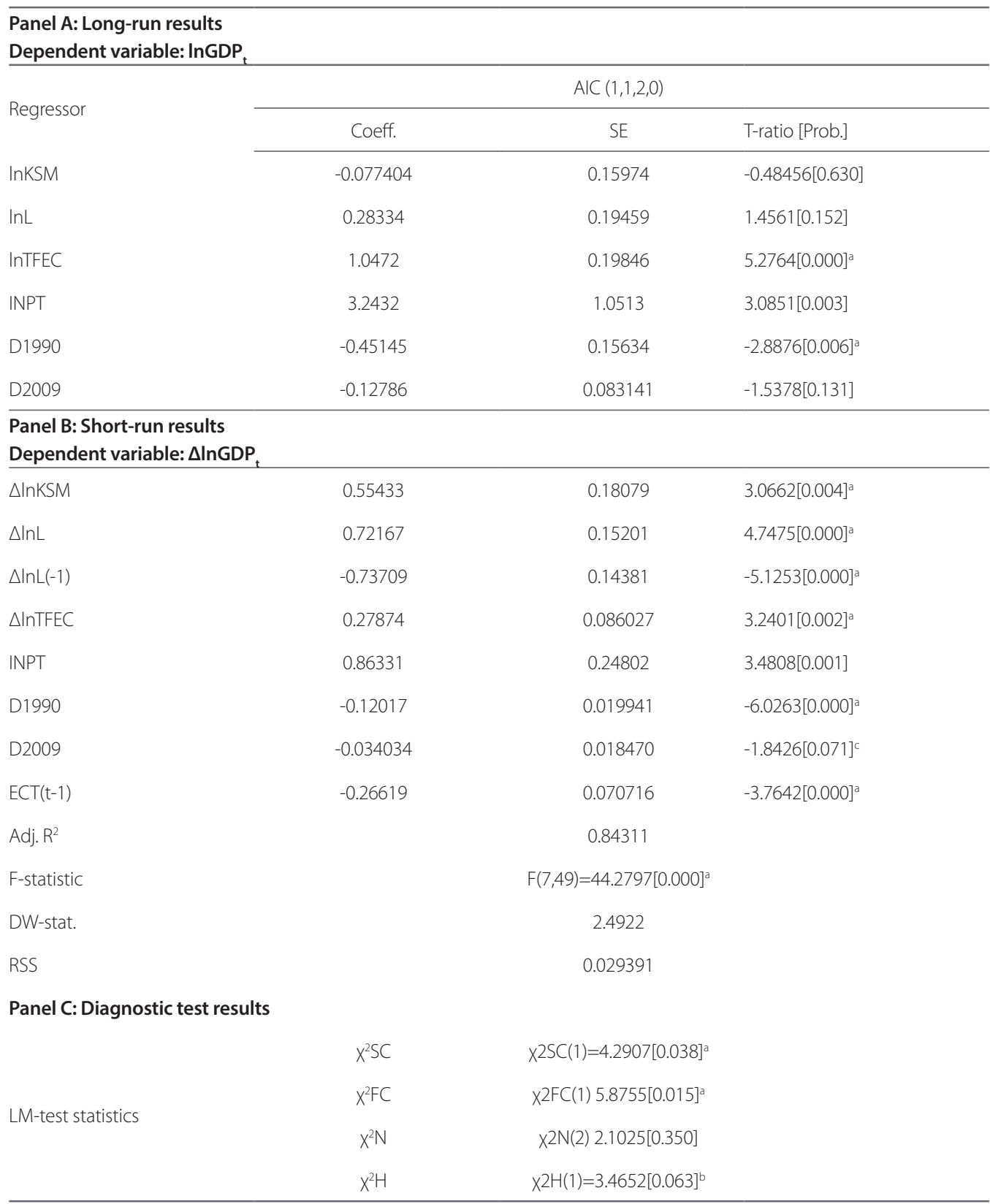

Note: AIC $(1,1,2,0)=$ Autoregressive distributed lag estimates based on Akaike's information criterion. ${ }^{a}, b, c$ Indicate the $1 \%, 5 \%$ and $10 \%$ significance levels, respectively. Coeff.=Coefficient; SE=Standard error; Prob.=Probability; INPT=Intercept; ECT=Error correction term; Adj. $R^{2}=$ Adjusted coefficient of determination; DW-stat.=Durbin-Watson statistic; RSS=Residual sum of squares; LM-test statistic=Lagrange multiplier test statistic; $S C=$ Test of residual serial correlation; FC=Ramsey's RESET test using square of the fitted values; $\mathrm{N}=$ Normality test based on a test of skewness and kurtosis of residuals; $\mathrm{H}=$ Heteroscedasticity test based on the regression of squared residuals on squared fitted values. Source: Authors' calculation using MICROFIT 4.1 
Table 5. Results of the multivariate VAR(2) estimates - Model 2

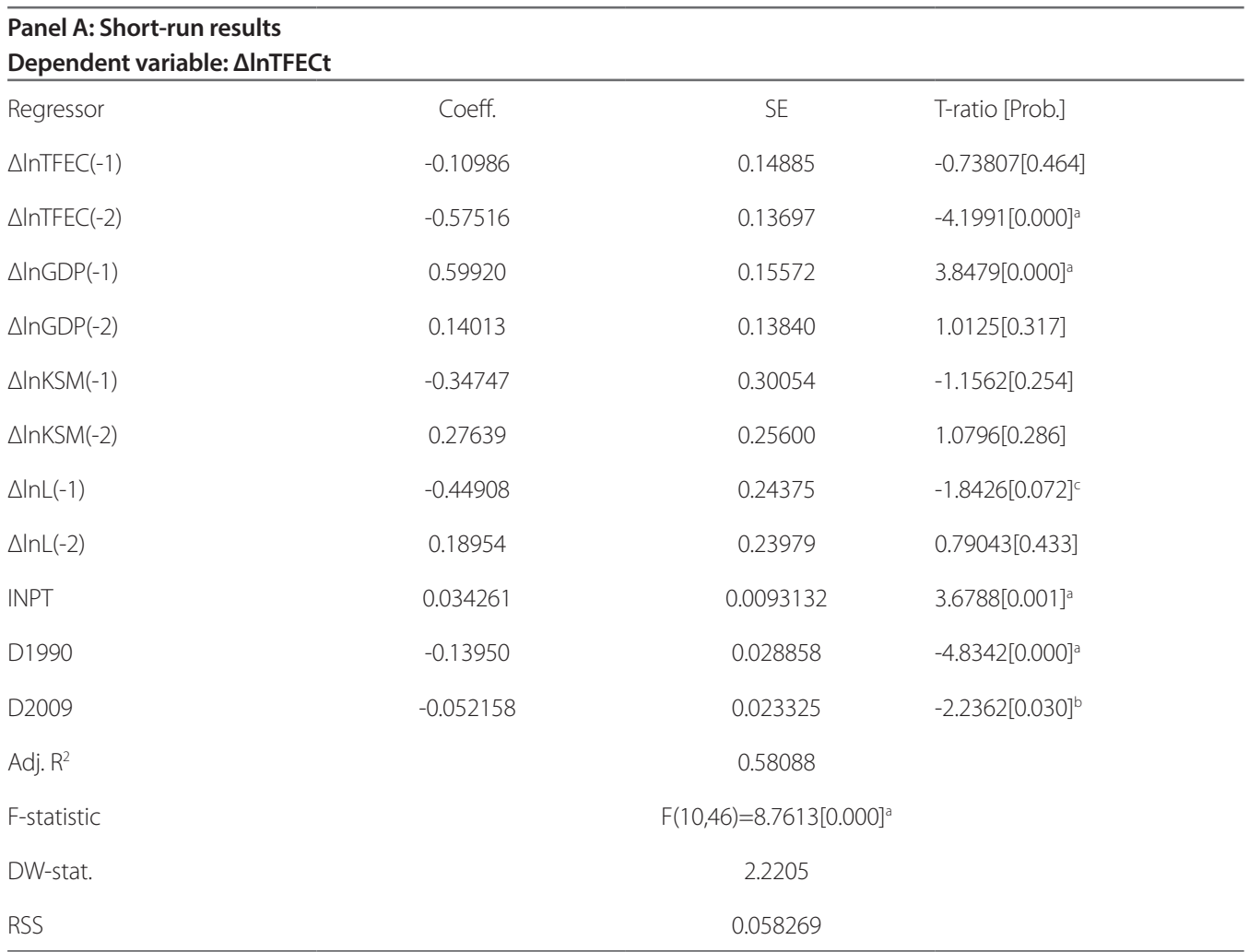

Panel B: Diagnostic test results

\begin{tabular}{lll}
\hline & $X^{2} \mathrm{SC}$ & $X^{2} \mathrm{SC}(1)=2.5187[0.113]$ \\
& $X^{2} \mathrm{FC}$ & $X^{2} \mathrm{FC}(1)=2.1066[0.147]$ \\
& $X^{2} \mathrm{~N}$ & $X^{2} \mathrm{~N}(2)=17.7535[0.000]^{*}$ \\
$X^{2} \mathrm{H}$ & $X^{2} \mathrm{H}(1)=11.8122[0.001]^{* *}$ \\
\hline
\end{tabular}

Note: a, b, c Indicate the 1\%,5\% and 10\% significance levels, respectively. The estimated VAR satisfies the stability condition (no root lies outside the unit circle). * Taking into consideration the normality test with residual correlation as an orthogonalization method (Doornik \& Hansen, 1994), we can accept the null hypothesis $\left(H_{0}\right)$ of residuals as multivariate normal (Jarque-Bera test $=12.47297, \mathrm{df}=8$, Prob. $=0.1313) .{ }^{*}$ According to White's test, there was no evidence of heteroscedasticity $($ Chi-sq. $=543.3125$, $\mathrm{df}=510$, Prob. $=0.1487$ ) when cross terms are included. Source: Authors' calculation using MICROFIT 4.1 and EViews 7.1

length was set to three according to Akaike's information criterion (AIC) and accompanied with the Final prediction error (FPE) as suggested by Ljung (1999). Detailed results for the lag order selection criteria prior to the Johansen co-integration test are available upon request. This evidence, in turn, provides suf- ficient argument for the existence of a valid long-run relationship among the variables.

Because we found a long-run relationship between the variables if real GDP is used as a dependent variable, the long-run and short-run coefficients are estimated using the associated ARDL and ECM. Ac- 
Table 6. Multivariate vector error correction model (VECM) estimates (InGDP, InTFEC)

\begin{tabular}{|c|c|c|c|c|}
\hline \multicolumn{5}{|c|}{ Equation no. (5) } \\
\hline \multicolumn{5}{|c|}{ 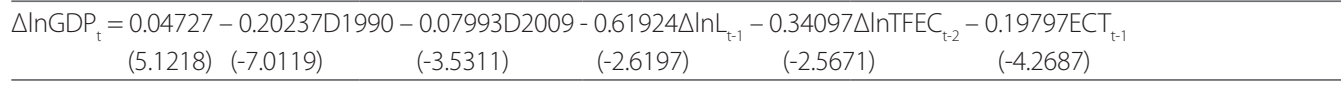 } \\
\hline \multicolumn{5}{|c|}{ Equation no. (6) } \\
\hline \multicolumn{5}{|c|}{ 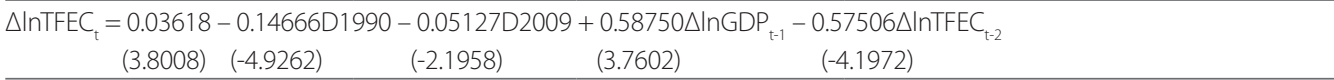 } \\
\hline & $\begin{array}{l}\text { Equation no. (5) } \\
\text { statistics }\end{array}$ & $\begin{array}{l}\text { Equation no. (6) } \\
\text { statistics }\end{array}$ & \multicolumn{2}{|r|}{ Diagnostic test results } \\
\hline Adj. $R^{2}$ & 0.701107 & $\begin{array}{l}0.580555 \\
0.057046\end{array}$ & Serial correlation & $\begin{array}{c}\text { Probabilities up to } 12 \text { lags are higher than } 1 \% \\
\text { significance level }\end{array}$ \\
\hline SE eq. & 0.034516 & 0.035605 & Normality* & Jarque-Bera test $=19.07241, \mathrm{df}=8$, Prob $=0.0145^{\mathrm{a}}$ \\
\hline F-statistic & 12.94162 & 8.046355 & Heteroscedasticity & Chi-sq. $=272.1268, d f=200$, Prob. $=0.0005$ \\
\hline
\end{tabular}

Note: *Orthogonalization: Residual correlation (Doornik-Hansen). ${ }^{\text {a }, ~ b, ~ c ~ I n d i c a t e s ~ 1 \%, ~ 5 \% ~ a n d ~ 10 \% ~ s i g n i f i c a n c e ~ l e v e l s, ~ r e s p e c-~}$ tively. Vector error correction equations only show significant variable(s). Figures in parenthesis are t-statistics. The block exogenity Wald test is computed to test the relationship between InGDP and InTFEC based on the multivariate framework. The test results confirm a bidirectional causal linkage between InGDP and InTFEC in the short run at the 1\% and 5\% significance levels, respectively. To preserve space, the causality results for capital stock and labor as well as the block exogenity Wald test are not presented but are available upon request. Source: Authors' calculation using EViews 7.1

cording to the AIC statistics, the specification selected ARDL $(1,1,2,0)$ as the best model. The results are presented in Table 4.

The results in Panel A show that the long-run impact of total final energy consumption on real GDP is positive and statistically significant even at the $1 \%$ level. A $1 \%$ increase in the total final energy consumption leads to a $1.0472 \%$ increase in the dependent variable. The coefficients for the dummy variables have the expected negative sign and are statistically significant, especially D1990. The results of the shortrun dynamic coefficients are presented in Panel B. Again, the total final energy consumption is statistically significant at the $1 \%$ level and is approximately 0.28. The findings in Table 4 also reveal that capital stock and employment are significantly related with GDP but only in the short run. Both dummy variables are statistically significant with negative signs in the short run. The ECT is found to be negative and statistically significant as well. For instance, Model 1 with GDP as the dependent variable implies that $26.62 \%$ (ECT $=-0.26619)$ of the preceding period's disequilibrium is eliminated in the current period.
The coefficient of determination (adjusted $\mathrm{R}^{2}$ ) shows that the total final energy consumption (and other statistically significant variables included in the regression equation) accounted for $84.31 \%$ of the changes in the economic growth. The selected model passes the standard diagnostic tests of serial correlation (no evidence of the residual autocorrelation problem), functional form (the model is correctly specified), normality (the residuals are normally distributed) and heteroscedasticity (LM test statistics show absence of the heteroscedasticity problem in the residuals).

When InTFEC was considered as a dependent variable, we found no evidence of co-integration. Therefore, the Granger causality test in a VAR framework is appropriate (see Table 5). The variables were transformed in first differences and the optimal lag was set to two. Detailed results on the lag order selection criteria prior to multivariate VAR estimates are available upon request.

The VAR estimates from Table 5 indicate that a $1 \%$ increase in the real GDP in the period $t-1$ increases the total final energy consumption by $0.59 \%$ in the period $t$. A certain amount of evidence shows that employ- 
ment affects lnTFEC and lnTFEC is determined by its lagged value. The combined results from Tables 4 and 5 indicate unidirectional causality from $\ln T F E C$ to $\ln G$ DP in the long run and bidirectional causality between those two variables in the short run.

To check the robustness of results, the short-run dynamic coefficients associated with the long-run relationship obtained from the Johansen co-integration test are presented in Table 6.

According to the results from Tables 3 (last row) and 6 , the direction of causality remains the same if compared with the results from Tables 4 and 5. The coefficients are nearly the same (size, signs and statistical significance) with one unexpected exception, namely, $\operatorname{lnTFEC}$ negatively affects $\ln$ GDP in the short run. Additionally, diagnostic test statistics show the existence of the heteroscedasticity problem in the residuals. Bearing in mind the discussion on the robustness of the ARDL and Johansen methods (and subsequently VECM) in small sample sizes, it is advisable to follow the ARDL results in the case of divergent results (Zachariadis, 2007).

\section{Discussion}

The multivariate co-integration analysis provided in the paper shows that co-integration exists in a relationship that includes GDP, capital, labor, and energy in Croatia and that energy is a significant factor in explaining GDP. Use of a multivariate framework analysis shows that energy Granger causes GDP in the short- and long-term periods, as indicated by the results of model 1, and GDP Granger causes energy only in the short run, as indicated by examination of the second model. These results contradict the bivariate analysis of Gelo (2009) and Vlahinic-Dizdarevic and Zikovic (2010), which found bivariate causality running from GDP to energy consumption. However, Borozan (2013) found the same causality that runs from energy consumption to GDP but only in the short run. Different empirical results could be explained by different methodologies and timeframes. This study differs from the previous three by including capital and labor variables and use of the longest time period, from 1952 to 2011.

The obtained results imply that energy consumption bears the burden of the short-run adjustments to re-establish the long-run equilibrium. In other words, highenergy consumption tends to lead to high economic growth, especially in the long run. A $1 \%$ increase in the total final energy consumption leads to a $1.0472 \%$ increase in the real GDP of Croatia in the long run. These empirical results have important implications for the Croatian economic and energy policy. The short-run causality running from energy consumption to GDP indicates that energy shortage can limit the dynamics of economic growth even in the short term. The direction of causality in the long run implies that Croatia should find ways to avoid adversely affecting economic growth by reducing energy consumption. The total final energy consumption per capita in Croatia is lower than the EU average, although a relatively high-energy intensity indicates that there is considerable potential to increase energy efficiency. Increased energy efficiency does not necessarily mean a reduction in total energy consumption. The explanation can be found in the so-called "rebound effect" or the situation in which new technologies that yield true cost savings stimulate the demand for energy services. This effect caused by more efficient technologies leads to increased use of energy, which is known as "macroeconomic feedback" (Howarth, 1997) or the rebound effect. In that context, Croatian economic policy must provide incentives for reforming the economic structure towards re-industrialization and more energy-efficient industries. Because the small Croatian economy is import dependent and strongly vulnerable to exogenous energy shocks, it is important to implement an energy strategy that will increase new investments in the installed energy capacities and diversify the energy mix to decrease import dependence. Because Croatia has significant potential for use of renewable energy sources, its energy mix should rely more heavily on renewable energy sources, including hydropower.

\section{Conclusion}

This paper examines co-integration and the causal relationship between total final energy consumption and real GDP in Croatia within a multivariate framework that includes capital stock and labor inputs during the 1952-2011 period. The results of the research fully support a positive long-run co-integrated relationship between production inputs and real GDP and the important role of energy in economic growth. A unidirectional causality is found that runs from total final energy consumption to real GDP in 
the long run, and bidirectional causality is found in the short run. These results contradict the other papers that addressed the causal relationship between energy consumption and economic growth in Croatia. Different empirical results could be explained by different methodologies and time frames because this study is the only one that includes capital and labor variables and the longest time period.

The obtained results imply that energy consumption bears the burden of the short-run adjustments to re-establish the long-run equilibrium. Energy consumption tends to trigger economic growth, especially in the long run, and a $1 \%$ increase in the total final energy consumption leads to a $1.0472 \%$ increase in the real GDP of Croatia. The results presented in this paper are important for policy makers because they show that energy could be a limiting factor in economic growth in the short- and long-run periods. This result means that Croatia should find ways to avoid adversely affecting economic growth by reducing energy consumption. Croatian economic policy must provide incentives for reforming the economic structure towards re-industrialization and more energy-efficient industries. Because the small Croatian economy is import dependent and strongly vulnerable to exogenous energy shocks, it is important to implement an energy strategy that will increase new investments in installed energy capacities and diversify the energy mix to decrease import dependence.

To the best of the authors' knowledge, this paper presents the first causality analysis between energy and economic growth in Croatia that uses a multivariate framework and notably long time span. The results obtained have important consequences for similar new EU member states in light of the ongoing desire to reduce energy consumption and reduce $\mathrm{CO}_{2}$ emissions. In the future, it may be interesting to investigate multivariate causality among $\mathrm{CO}_{2}$ emissions, energy consumption and economic growth in Croatia and other EU Member States.

\section{References}

Acaravci, A. (2010). The causal relationship between electricity consumption and GDP in Turkey: Evidence from ARDL bounds testing approach. Economic Research, 23 (2), 34-43.
Akarca, A. T., Long, T. V. (1980). On the relationship between energy and GNP: a re-examination. Journal of Energy and Development, 5 (2), 326-331.

Apostolakis, B. E. (1990). Energy-capital substitutability/complementarity: The dichotomy. Energy Economics, 12 (1), 48-58.

Asafu-Adjaye, J. (2000). The relationship between energy consumption, energy prices and economic growth: time series evidence from Asian developing countries. Energy Economics, 22 (6), 615-625.

Ayres, R. U., Warr, B. (2009). The economic growth engine. Cheltenham, UK: Edward Elgar Publishing.

Bahovec, V., Erjavec, N. (2009). Uvod u ekonometrijsku analizu [Introduction to econometric analysis]. Zagreb: Element.

Bartleet, M., Gounder, R. (2010): Energy consumption and economic growth in New Zealand: Results of trivariate and multivariate models. Energy Policy, 38 (7), 3508-3517.

Berndt E. R. (1978). Aggregate energy, efficiency, and productivity measurement. Annual Review of Energy, 3, 225-273.

Berndt, E. R., Wood, D. O. (1979). Engineering and econometric interpretations of energy-capital complementarity. American Economic Review, 69 (3), 342-354.

Binh, P. T. (2011). Energy consumption and economic growth in Vietnam: Threshold co-integration and causality analysis. International Journal of Energy Economics and Policy, 1 (1), 1-17.

Borozan, D. (2013). Exploring the relationship between energy consumption and GDP: Evidence from Croatia. Energy Policy, 59, 373-381.

Chandran, V. G. R., Sharma, S., Madhavan, K. (2010). Electricity consumption-growth nexus: The case of Malaysia. Energy Policy, 38 (1), 606-612.

Chang, T., Fang, W., Wen, L. F. (2001). Energy consumption, employment, output and temporal causality: Evidence from Taiwan based on co-integration and error-correction modeling techniques. Applied Economics, 33 (8), 1045-1056.

Chontanawat, J., Hunt, L. C., Pierse, R. (2008). Does energy consumption cause economic growth? Evidence from a systematic study of over 100 countries. Journal of Policy Modeling, 30 (2), 209-220.

Chow, G. C. (1960). Tests of equality between sets of coefficients in two linear regressions. Econometrica, 28 (3), 591-605. 
Croatian Bureau of Statistics (2012). Statistical yearbook of Croatia. Retrieved from http://www.dzs. hr/Hrv_Eng/ljetopis/2012/sljh2012.pdf

Dantama, Y. U., Abdullahi, Y. Z., Inuwa, N. (2012). Energy consumption-economic growth nexus in Nigeria: An empirical assessment based on ARDL bound test approach. European Scientific Journal, 8 (12), 141-157.

Dergiades, T., Tsoulfidis, L. (2011). Revisiting residential demand for electricity in Greece: New evidence from the ARDL approach to co-integration analysis. Empirical Economics 41 (2), 511-531.

Dickey, D. A., Fuller, W. A. (1979). Distribution of the estimators for autoregressive time series with a unit root. Journal of the American Statistical Society, 74, 427-431.

Doornik, J.A., Hansen, H. (1994). An omnibus test for univariate and multivariate normality. Oxford Bulletin of Economics and Statistics, 70, 927-939.

Druzic, I., Tica, J. (2002). Dinamika i kontroverze gospodarskog razvitka Hrvatske [Dynamics and controversy of Croatia's economic development]. In I. Druzic (Ed.), Stabilizacija-participacija-razvoj, Zbornik radova znanstvenog skupa povodom 80. obljetnice rodjenja akademika Jakova Sirotkovica [Scientific conference proceedings in the occasion of the 80th birth anniversary of the academician Jakov Sirotkovic]. (pp. 107-125). Zagreb: Faculty of Economics, University of Zagreb.

Elliott, G., Rothenberg T. J., Stock, J. H. (1996). Efficient tests for an autoregressive unit root. Econometrica, 64 (4), 813-836.

Energy Institute Hrvoje Pozar (December 2012). Energy in Croatia 1945-2011. Zagreb. Available at http://www.eihp.hr/

Engle, R. F., Granger, C. W. J. (1987). Co-integration and Error Correction: Representation, Estimation and Testing. Econometrica, 55 (2), 251-276.

Erol, U., Yu, E. S. H. (1987). Time series analysis of the causal relationships between US energy and employment. Resources Energy, 9, 75-89.

Esso, L. J. (2009). Co-integration and causality between financial development and economic growth: evidence from ECOWAS countries. European Journal of Economics, Finance and Administrative Sciences, $16,112-122$.
Fatai, K., Oxley, L., Scrimgeour, F. (2004). Modeling the causal relationship between energy consumption and GDP in New Zealand, Australia, India, Indonesia, the Philippines and Thailand. Mathematics and Computer in Simulation, 64 (3), 431-445.

Gelo, T. (2009). Causality between economic growth and energy consumption in Croatia. Proceedings of Rijeka Faculty of Economics - Journal of Economics and Business, 27 (2), 327-348.

Ghali, K. H., El-Sakka, M. I. T. (2004). Energy use and output growth in Canada: A multivariate cointegration analysis. Energy Economics, 26 (2), 225-238.

Glasure, Y. U. (2002). Energy and national income in Korea: Further evidence on the role of omitted variables. Energy Economics, 24 (4), 355-365.

Granger, C. W. J. (1969). Investigating causal relationship by econometric models and cross-spectral methods. Econometrica, 37 (3), 424-438.

Gujarati, D. N., Porter, D. C. (2009). Basic econometrics $\left(5^{\text {th }}\right.$ ed.). New York, NY: McGraw-Hill Companies Inc.

Hall, R. E., Jones, C. I. (1999). Why do some countries produce so much more output per worker than others?. The Quarterly Journal of Economics, 114 (1), 83-116.

Hannon, B. M., Joyce, J. (1981). Energy and technical progress. Energy 6, 187-195.

Hondroyiannis, G., Lolos, S., Papapetrou, E. (2002). Energy consumption and economic growth: Assessing the evidence from Greece. Energy Economics, 24 (4), 319-336.

Howarth, R. B. (1997). Energy efficiency and economic growth. Contemporary Economic Policy, 15 (4), 1-9.

Johansen, S. (1988). Statistical analysis of co-integration vectors. Journal of Economic Dynamics Control, 12 (2-3), 231-254.

Johansen, S., Juselius, K. (1990). Maximum likelihood estimation and inference on co-integration-with applications to the demand for money. Oxford Bulletin of Economics and Statistics, 52 (2), 169-210.

Kamps, C. (2004). New estimates of government net capital stocks for 22 OECD countries 1960-2001 (Working paper No. 67). International Monetary Fund.

Kouakou, A.K. (2011). Economic growth and electricity consumption in Cote d'Ivoire: Evidence from time series analysis. Energy Policy, 39 (6), 3638-3644. 
Kraft, J., Kraft, A. (1978). On the relationship between energy and GNP. Journal of Energy and Development, 3 (2), 401-403.

Kwiatkowski, D., Phillips, P. C. B., Schmidt, P., Shin, Y. (1992). Testing the Null Hypothesis of Stationarity Against the Alternative of a Unit Root: How Sure Are We That Economic Time Series Have a Unit Root? Journal of Econometrics, 54 (1-3), 159-178.

Kyriacou, G.A. (1991). Level and growth effects of human capital: a cross-country study of the convergence hypothesis (Working Papers No. 91-26). C.V. Starr Center for Applied Economics.

Lee, C. C. (2005). Energy consumption and GDP in developing countries: A cointegrated panel analysis. Energy Economics, 27 (3), 415-427.

Lütkepohl, H. (2005). New introduction to multiple time series analysis. Berlin: Springer-Verlag.

Ljung, L. (1999). System identification - theory for the user ( $2^{\text {nd }}$ ed.). Upper Saddle River, NJ: Prentice Hall.

MacKinnon, J. G. (1996). Numerical distribution functions for unit root and co-integration tests. Journal of Applied Econometrics, 11 (6), 601-618.

MacKinnon, J. G., Haug, A. A., Michelis, L. (1999). Numerical distribution functions of likelihood ratio tests for co-integration. Journal of Applied Econometrics 14 (5), 563-577.

Maddala, G. S., Kim, I. M. (1998). Unit roots, co-integration and structural change. Cambridge, UK: Cambridge University Press.

Masih, A. M. M., Masih, R. (1996). Energy consumption, real income and temporal causality: results from a multi-country study based on co-integration and error-correction modeling techniques. Energy Economics, 18 (3), 165-183.

Masih, A. M. M., \& Masih, R. (1997). On the temporal causal relationship between energy consumption, real income, and prices: Some new evidence from Asian-energy dependent NICs based on a multivariate cointegration/vector error-correction approach. Journal of Policy Modeling, 19 (4), 417-440.

Narayan, P. K. (2005). The saving and investment nexus for China: evidence from cointegration tests. Applied Economics, 37 (17), 1979-1990.

Nelson, C. R., Plosser, C. I. (1982). Trends and random walks in macroeconomic time series - some evidence and implications. Journal of Monetary Economics, 10 (2), 139-162.
Ng, S., Perron, P. (2001). Lag length selection and the construction of unit root tests with good size and power. Econometrica, 69 (6), 1519-1554.

Oh, W., Lee, K. (2004). Causal relationship between energy consumption and GDP revisited: the case of Korea 1970-1999, Energy Economics, 26 (1), 51-59.

Ouédraogo, I. M. (2010). Electricity consumption and economic growth in Burkina Faso: A co-integration analysis. Energy Economics, 32 (3), 524-531.

Ozturk, I., Acaravci, A. (2010). The causal relationship between energy consumption and GDP in Albania, Bulgaria, Hungary and Romania: Evidence from ARDL bound testing approach. Applied Energy, 87 (6), 1938-1943.

Ozturk, I., Acaravci, A. (2011). Electricity consumption and real GDP causality nexus: Evidence from ARDL bounds testing approach for 11 MENA countries. Applied Energy 88 (8), 2885-2892.

Pasalic, Z. (1999). Osnove hrvatske gospodarstvene infrastructure [Basics of Croatian economic infrastructure]. Split:Univeristy of Split, Faculty of Economics.

Pesaran, M. H., Shin, Y., Smith, R. J. (2001). Bounds testing approaches to the analysis of level relationships. Journal of Applied Econometrics, 16 (3), 289-326.

Phillips, P. C. B., Perron, P. (1988). Testing for a unit root in time series regressions. Biometrica, 75 (2), 335-346.

Raguz, I., Druzic, I., Tica, J. (2011). Human capital in growth accounting: The case of Croatia. Journal of International Scientific Publications: Educational Alternatives, 9, 185-198.

Sari, R., Ewing, B. T., Soytas, U. (2008). The relationship between disaggregate energy consumption and industrial production in the United States: An ARDL approach. Energy Economics, 30 (5), 2302-2313.

Shahbaz, M., Tang, C.F., Shahbaz Shabbir, M. (2011). Electricity consumption and economic growth nexus in Portugal using cointegration and causality approaches. Energy Policy, 39 (6), 3529-3536

Soytas, U., Sari, R. (2006). Energy consumption and income in G-7 countries. Journal of Policy Modeling, 28 (7), 739-750.

Soytas, U., Sari, R. (2007). The relationship between energy and production: Evidence from Turkish manufacturing industry. Energy Economics, 29 (6), 1151-1165. 
Stern D. I. (1997). Limits to substitution and irreversibility in production and consumption: a neoclassical interpretation of ecological economics. Ecological Economics, 21 (3), 197-215.

Stern, D. I. (1999). Is energy cost and accurate indicator of natural resource quality? Ecological Economics, 31 (3), 381-394.

Stern, D. I. (2000). A multivariate cointegration analysis of the role of energy in the US macroeconomy. Energy Economics, 22 (2), 267-283.

Stresing, R., Lindenberger, D., Kümmel, R. (2008). Cointegration of output, capital, labor and energy (Working Paper, No. 08.04). Institute of Energy Economics at the University of Cologne. Retrieved from http://www.ewi.uni-koeln.de/fileadmin/ user_upload/Publikationen/Working_Paper/ EWI_WP_08-04_Cointegration-of-Output.pdf

Tang, C. F., Shahbaz, M. (2011). Revisiting the electricity consumption-growth nexus for Portugal: Evidence from a multivariate framework analysis (Paper No. 28393). Munich Personal RePEc Archive. Retrieved from http://mpra.ub.uni-muenchen.de/28393

Tintner, G., Deutsch, E., Rieder, R., Rosner, P. (1977). A production function for Austria emphasizing energy. De Economist, 125 (1), 75-94.

Toda, H. Y. (1994). Finite sample properties of likelihood ratio tests for co-integration ranks when linear trends are present. The Review of Economics and Statistics, 76 (1), 66-79.

Vlahinic-Dizdarevic, N., Zikovic, S. (2010). The role of energy in economic growth: the case of Croatia. Zbornik radova Ekonomskog fakulteta u Rijeci, 28 (1), 35-60.

Winters, P. R. (1960). Forecasting sales by exponentially weighted moving averages. Management Science, 6 (3), 324-342.

World Bank (2012). World development indicators 2012. Washington, D.C., World Bank.

Yang, H. Y. (2000). A note on the causal relationship between energy and GDP in Taiwan. Energy Economics 22 (3), 309-317.

Yu, E. S. H., Hwang, B. K. (1984). The relationship between energy and economic growth in Korea. Applied Energy, 83, 1181-1189.

Yu, E. S. H., Choi, J. Y. (1985). The causal relationship between energy and GNP: an international comparison. Journal of Energy and Development, 10 (2), 249-272.
Zachariadis, T. (2007). Exploring the relationship between energy use and economic growth with bivariate models: New evidence from G-7 countries. Energy Economics, 29 (6), 1233-1253.

Zikovic, S., Vlahinic-Dizdarevic, N. (2011). Oil Consumption and Economic Growth Interdependence in Small European Countries. Economic research 24 (3), 15-32.

\section{Acknowledgements}

This article was fully supported by the Croatian Science Foundation under project number IP-2013-11-2203. Additionally, this work is the result of the scientific project "Economic effects of electricity sector reforms on sustainable economic growth", no. 13.02.1.3.05, financed by University of Rijeka. 